\title{
Arshi Pipa as a National and International Figure
}

\author{
Hektor Çiftja \\ For the "3rd International Conference on Educational Sciences" ICES \\ "Aleksandër Xhuvani" University, Elbasan, Albania \\ Email: hciftja@yahoo.co.uk
}

\section{Doi:10.5901/jesr.2014.v4n2p328}

\section{Arshi Pipa: Academia and the Relentless Struggle of the American-Albanian Scholar and Writer}

In "The Columbia Literary History of Eastern Europe since 1945" (Columbia University press, New York, 2008), Harold B. Segel states that Arshi Pipa published a series of books of more-or-less scholarly nature that sought to expose the Albanian dictatorship in the way that Paul Goma sought to expose the Romanian tyranny under Nicolae Ceausescu through his fiction (Segel, 2008). That was undoubtedly one of the aspects of Arshi Pipa's work, most of whose volumes in the English language being either a contribution to Italian studies - such was the case for Montale - or a dedication to the exposure of the richness and faults of the Albanian culture, literature, and contemporary politics to the English speaking audience.

Our paper approaches the multilateral personality of Arshi Pipa (1920-1997) by observing him as a national as well as an international figure. Due to the nature of the conference, more details and arguments will be presented in the published paper, and only a brief account of our findings and considerations are going to be introduced now.

Arshi Pipa was, undoubtedly, an Albanian writer, poet, literary translator, and political writer. But he was more than that. Having a multicultural education, holding a degree on philosophy from Florence University in Italy, and fulfilling the requirements of the professorship of North-American Colleges, his scholarly work includes a cultural studies component which has either passed in silence or been misinterpreted. Originating from a country which is a significant crossing path of western and eastern civilizations, such as Albania, and being educated both in a catholic school during mornings and a Muslim school (medrese) during afternoons throughout his childhood, excelling in philosophy in Florence, Italy, and teaching in the North-American Universities in 1970s, his body of English writing on Albania and Albanian culture was bound to be an epitome of the practice of cultural studies exercised on the aforementioned field of inquiry. Despite his probably better recognition for introducing the Italian poet Eugenio Montale to the English-speaking academia (Pipa 1968), followed by Montale who was awarded the Nobel Prize in literature in 1975, Pipa's main academic focus and preoccupation continued to remain the Albanian Studies and Culture as he wanted the english-speaking academia to be introduced to them.

\section{The Albanian Writer and Communism}

In one of his writings on Faik Konica, Pipa states: we support the belief that the key to the art of a writer stands on his own personality" (Pipa 1944). Pipa's work my well be better comprehended within the frame of his academic upbringing. Nor are the actual social and historical circumstances in which he had to write and communicate through his work of any less significance. (The Gulags of Former Eastern European Dictatorships are not exactly the ideal "writer's corner" to produce any kind of literary or philosophical written paper).

Our paper approaches his multilateral personality, especially his ideology and anti-Stalinism by examining his intellectual personality as well as taking a systematic view on his corpus of publications. We support the thesis that- in his work- two dimensions permeating his written papers can be traced: firstly, the patriotic dimension which is fundamental in most of his publications in the English language. And secondly, but of no lesser significance than the former is that of internationalism and multiculturalism of that kind that overcomes the narrow-mindedness of the old-fashioned nationalism and views the Albanian culture and politics from a very broad perspective, a perspective rooted in the western thought which Pipa learned from Italian philosophers in his youth and crafted to perfectionism through the spirit of academic discipline of the Cultural Studies which he researched and adopted in the later years.

The denouncement and exposure of Stalinism and dictatorship of Albania to the English-speaking academia, 
indeed permeates most of his writing and research papers. This component brings together in a very easily notable manner both the aforementioned dimensions: the nationalistic and internationalist one.

At an early age, by the end of World War II, when he was in his twenties, he published essays on some emblematic figures of the Albanian culture, such as Migjeni, Noli, Fishta and others (Pipa 1944). What we note "in common" to all the profiles he writes about, is that Pipa views them, examines them, hails them and in more then one case calls them "Missionaries", missionaries of patriotism, missionaries of enlightening their people. Not only does he highly appreciate this component when observed to other writers, but he himself takes the role of a missionary in his later writings. Being a "missionary to your people" and an "educator to your nation" becomes another component that permeates all of his publications. The special position of an "educator of your people" bears in itself a strong element of internationalism. His essays and research papers in the English language offer complete evidence on this.

As a highly cultivated scholar with a degree in philosophy and as a distinct philosopher himself, he could not but observe the issues and concerns of his mother- land from a perspective much broader than that of a simplistic nationalism. However, the spirit and the international strata that can be noted in his publications do have a purely political component, which has either been passed in silence or misinterpreted.

After examining the scholarly writing of Pipa for more then ten years now, we have come to the conclusion that the work of Pipa, whether it is in poetry, essays, philosophy, literary studies, Albanology and politology is characterized by:

1. A commitment to patriotic issues like the ones that deal with the national case as well as problems of the Albanian nation. These writings are characterized by the spirit of an education that Pipa believes should be given from a philosopher to his people, once by teaching them about the literary criticism and literary taste or gusti, once by recounting them about the horrors of prisons and dictatorship, somewhere by teaching them how to escape from communism, and somewhere else by understanding the personalities of the Albanian culture.

2. The pervasive ideology of all Pipa's works is characterised by an extremely democratic and humanitarian ideology, as expressed somehow openly in "An outline on the concept of life", or elsewhere in the thoughts of the scholar when he deals with the problems of national culture, that are in principle covered almost all over his works. This democratic and humanitarian ideology has all the features of a western academic style of Marxism expressed in the issues of culture. Probably, the only elitist thing in him is the the taste in literature, or II Gusto Literaio that originates in his talent, and is cultivated through a variety of good readings ( see "Montale e Dante"), and even teachings from great philosophers like Bergson, Kroçe, Viko, De Sanctis etc.

3. The largest volume of his work consists of writings where the problems of Albanian culture are seen from a western multiculturalists perspective, like in the case of Migjeni where the effects of Albanian culture are investigated, but similarly at De Rada and in folklore alike. The Albanian authors obviously appreciated by him the most are De Rada, Migjeni, and Noli, all three seen as both an expression of the multiculturalism era and of the country where they come, a multiculturalism which is expressed through the instruments of literature, poetry and that can be noted even in their creative personality.

4. His research papers on Italian studies, successfully conducted in American universities and written in the English language, indeed demonstrate his trend towards multiculturalism. Here he takes this feature further on to another stage, so moving himself to the world of western academia, which is by his own definition fundamentally international

This section aims to outline the intellectual biography of Pipa through a critical analysis of his writings and speeches that show his commitment to use research, academic writing, and volumes of studies in order to expose the atthe- time- unknown aspects the Albanian dictatorship system to the western world. Due to the nature of our speech, the examples can not be but limited ( the full published paper is going to provide elabortate details and arguments) and focus is narrowed down to the anticommunist element permeating Pipa's work.

"And I have sworn upon my brother's blood

to fight Stalinism no less than Fascism

to the last drop of my blood"

The above verses belong to the "Autobiografia" ("Autobiography") poetry taken from the book entitled the same. This edition of poetry in several languages was made ready for publication in 1988 . At that time Pipa was in his 60s, and this collection of poetry was like a testament to him. As the author claims, those writings were composed in 1970-1971 by which time Pipa had returned to Italy to carry some scientific research. It is no doubt that such verses help us create his intellectual biography, and they are a self-evident portrayal of the anti-dictatorial dimension that covers all of his work, be 
it the creative, or the scholastic one.

Indeed, Pipa's anti-Communism marks a personality value and an extraordinarily progressive courage. In a piece of study or creative work, that can not be a value per sé; the main values of a scholarly work lying mainly on the scientific apparatus and its use, metodology and analytical skills, just like the values of a work of art lie in the basic qualities of art and in the notion of literature, rather then pure content. But comprehending Pipa's work does require an understanding of his anticommunistic dimension that is noticeable everywhere in his work.

In 2008, Harold B. Segel, who published "The Columbia Literary History of Eastern Europe since 1945 ", in the publishing house of the Columba University, New York, dealt with Pipa in the 6th chapter of his work, under the title "Writers behind bars / the East European literature of prison from 1945-1990." According to Segel, since the collapse of the former Soviet Union, the western world is increasingly understanding the endless network of prison camps known as "gulags", that existed in the grand state. It was the work of Soltzenicini that would open a window on what was happening in these camps, but what did really happen in the other European countries of the socialist camp was a different story. The dictatorship model operating in most of these countries would make us understand the truth about such concentration camps only after the overthrow of those regimes. In this chapter the author tries to explore the nature of these camps and prisons, by mainly focusing on East European writers convicted there. This is firstly reached by throwing light over the circumstances that led to the imprisonment of certain writers, and on the other hand by examining the impact that the prison experience had in the literary production of such authors, be it in the field of fiction or in other writings that aimed to denounce what was happening indeed (expository literary output). When everything is already said and done in relation to these camps, as Segel notes, there will be namely the literary community of Eastern Europe that will have presented the most vivid and touching writings about such prison camps. It is precisely on this fact where Segel bases his entire chapter "writers behind bars."

Through this approach Segel's portrayal starts with Romania, continues with all the countries and authors of Eastern Europe, and concludes with the Democratic Republic of Germany. In this overview, Albania comes second after Romania. According to the author, this is not because of the size of the country, but because when it comes to the conditions of the prison camps during the regime of dictator Enver Hoxha, Albania is the closest country to Romania. Despite being more educated than Ceausescu, Hoxha was equally violent in all of his policies. Finally, just like in the case of Romania, the main target of the secret police, the Security, was the small intellectual elite.

Arshi Pipa is the first writer discussed in this piece of work, firstly because of chronological reasons, but most importantly because of his deep hatred towards Hoxha's regime and communism in general, which made him publish, while in exile, a series of books based on research studies that aimed to expose the Albanian dictatorship. At this point, Segel finds strong parallels between the personality of Arshi Pipa in Albania and that of Paul Goma (I. 1935) in Romania. Paul Goma is the most famous dissident of Ceausescu's Romania and the first Romanian writer who threw light on the way how Romania was transforming to a huge prison camp in 1948-1964. What Goma did through his literary work on the Ceausescu's dictatorship, Arshi Pipa carried out in exile through his scholastic work. Segel notes that if Albanians produced no imprisoned dissident or student of a productivity literary rate and level comparable to Paul Goma, due to the underdevelopment of Albanian society under Hoxha's regime and because of the prolonged violations that he caused to the writers, it still does not mean that other author and writing should be underestimated. In fact, the opposite is true, and Pipa is an example of this. While in exile, he published a series of books based on a scholarly nature that aimed to expose the Albanian dictatorship to the West similarly to the Romanian writer, Goma, who tried through his literary work, to expose the Romanian tyranny under Ceausescu. Segel calls Pipa a talented and courageous writer and then proceeds by giving some biographical data about his poetic work and studies in the realm of Italian Studies.

Neli

A peasant he was from Central Albania,

Plagued by malaria, rheumatism, an unhealed

knee wounded while a guerrilla fighter,

when his brothers were killed.

Suffering also from hunger

for having left at home

three motherless children

in care of his old folks.

Yet in such need and misery

I never saw or heard him

complain, get angry, envy 


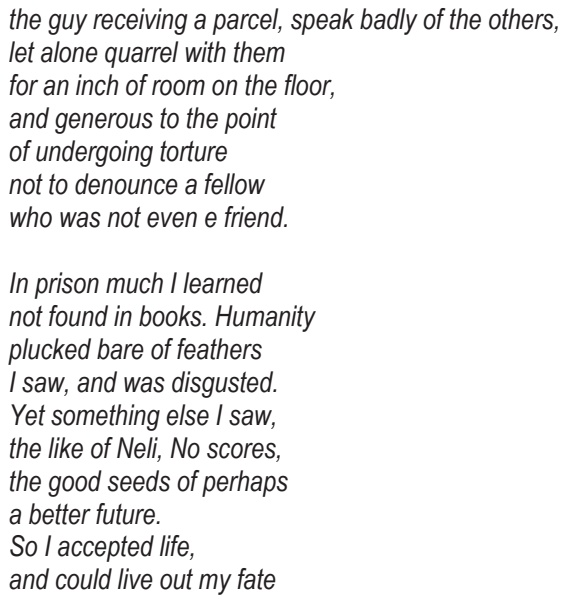

Pipa reached the highest possible position that he was committed to not only as an anti Stalinist but also as a champion of democracy all over the Albanian territories. So he devoted himself to the cause of human rights of the Albanian population in Kosovo. He published two major political studies on this topic: "The political development of Albanian state, 1912-1962" in 1962, and "Studies on Kosovo" published in the English language in 1984.

Considering that the- more- lengthy published paper of this honorable conference will provide chances for more elaborate arguments and details, I would like to end on a conclusive note. As his fellow colleagues at the University of Minessota put it in his obituary,

"Arshi Pipa was an outstanding teacher. A former student remembers him as a gentleman and humanitarian: "His sincere admiration for the property of Dante, Petrarca, Leopardi, Pascoli, Ungareti and Montale influenced all his students. His analytical method didn't have a label, nor did it need one. It was born of his intelligence, education and passion for poetry. his insightful criticism of my work, though often acute and sever, remains, even today, very valuable. I treasure most the respect he paid to my parents when my brother died."

\section{References}

Segel, Harold: "The Columbia Guide to the Literature of Eastern Europe Since 1945 (2003)"

Pipa, Arshi: Montale and Dante", Univ Of Minnesota Press; 1968

Pipa, Arshi: "Kritika-esse 1940-1944", Botimet "Princi" Tiranë 2006

Pipa, Arshi: "autobiography", Botimet Phoenix 2000

Pipa, Arshi: Albanian folk verse: Structure and genre; Trofenik 1978

Pipa, Arshi: Albanian literature: Social perspectives ; Trofenik 1978

Pipa Arshi: Hieronimus De Rada, Trofenik, 1978

Pipa, Arshi: Contemporary Albanian Literature, East European Monographs; 1991

Pipa, Arshi: The Politics of Language in Socialist Albania; East European Monographs; 1989

Pipa, Arshi: Studies On Kosova; East European Monographs; 1984 